\title{
Effects of cold versus hot compress on pain in university students with primary dysmenorrhea
}

\author{
Efeitos da compressa fria versus quente sobre a dor em universitárias com dismenorreia primária
}

Gyan Karla Advíncola dos-Santos ${ }^{1}$, Natália Cristina de Oliveira Vargas e Silva ${ }^{1}$, Fábio Marcon Alfieri ${ }^{1}$

DOI 10.5935/2595-0118.20200006

\section{ABSTRACT}

BACKGROUND AND OBJECTIVES: Dysmenorrhea is the most common gynecological complaint among young women. Several therapeutic resources have been studied, aiming at reducing pain. The objective of this study was to identify the influence of cold or hot compresses on pain intensity and pressure pain tolerance thresholds in women with primary dysmenorrhea.

METHODS: A single-blind randomized clinical study involving 40 young women divided into two groups: hot compress or cold compress, applied for 20 minutes on the lower abdomen and lower back regions. Pressure pain tolerance thresholds were evaluated by algometry in the vastus medialis, gluteus maximus, lumbar paravertebral muscles and supraspinatus ligaments L4-L5 and L5S1. Pain intensity was assessed by the visual analog scale.

RESULTS: No significant changes in pressure pain tolerance thresholds were observed immediately after the application of the compresses, nor 30 minutes later. The comparison of the variation in the effect of changes showed no differences between the intervention groups, either regarding the pressure pain tolerance thresholds or the visual analog scale. However, both groups had a significant reduction in the visual analog scale right after the application and 30 minutes after the end of the intervention. Nevertheless, right after the use of the compresses, as well as 30 minutes after its end, the group that received the cold compress had a more significant reduction in pain intensity $(\mathrm{p}=0.002$ and $\mathrm{p}=0.004$, respectively).

CONCLUSION: Cold or hot compresses did not produce changes in pressure pain tolerance thresholds. However, pain perception was lower after this treatment, especially in the group using cold compresses.

Gyan Karla Advíncola dos-Santos - (Dhttps://orcid.org/0000-0002-1442-7713;

Natália Cristina de Oliveira Vargas e Silva - Dhttps://orcid.org/0000-0002-0747-9478;

Fábio Marcon Alfieri - (Dhttps://orcid.org/0000-0002-5242-3246.

1. Centro Universitário Adventista de Sâo Paulo, Mestrado em Promoção da Saúde, São Paulo, SP, Brasil.

Submitted on October 10, 2019

Accepted for publication on December 11, 2019

Conflict of interests: none - Sponsoring sources: none.

Correspondence to:

Centro Universitário Adventista de São Paulo

Mestrado em Promoção da Saúde

Estrada de Itapecerica, 5859, Jardim IAE

05858-001 São Paulo, SP, Brasil.

E-mail: fabiomarcon@bol.com.br fabio.alfieri@unasp.edu.br

(C) Sociedade Brasileira para o Estudo da Dor
Keywords: Dysmenorrhea, Pain measurement, Physical therapy modalities.

\section{RESUMO}

JUSTIFICATIVA E OBJETIVOS: A dismenorreia é a queixa ginecológica mais comum em mulheres jovens, e diversos recursos terapêuticos visando a redução da dor vêm sendo testados. $\mathrm{O}$ objetivo deste estudo foi verificar a influência de compressas frias ou quentes sobre a intensidade da dor e o limiar de tolerância de dor à pressão em mulheres com dismenorreia primária.

MÉTODOS: Estudo clínico randomizado simples encoberto envolvendo 40 jovens divididas em dois grupos: compressa quente ou compressa fria, aplicadas por 20 minutos nas regióes do abdômen inferior e lombar. $\mathrm{O}$ limiar de tolerância de dor à pressão foi avaliado por algometria nos músculos vasto medial, glúteo máximo, paravertebrais lombares e ligamentos L4-L5 e L5-S1. A intensidade da dor foi avaliada pela escala analógica visual.

RESULTADOS: Não foram observadas alteraçôes significantes imediatamente após a aplicação das compressas, nem tampouco 30 minutos após a aplicação no que concerne aos limiares de tolerância de dor à pressão. A comparação da variação do efeito das intervençóes não revelou diferenças entre os grupos de intervenção, tanto em relação aos limiares de tolerância de dor à pressão, quanto em relação à escala analógica visual. Entretanto, ambos os grupos apresentaram redução significante na escala analógica visual logo após a aplicação e depois de 30 minutos do término em relação ao momento anterior à intervenção. Apesar disso, logo após a aplicação da compressa, bem como 30 minutos após o término, o grupo que usou compressa fria exibiu maior redução da intensidade da dor ( $\mathrm{p}=0,002 \mathrm{e} \mathrm{p}=0,004$, respectivamente). CONCLUSÁO: Compressas frias ou quentes não provocaram alteraçôes no limiar de tolerância de dor à pressão, porém, a percepção da dor foi menor após a aplicação do tratamento, especialmente no grupo que fez uso da compressa fria.

Descritores: Dismenorreia, Mensuração da dor, Modalidades de fisioterapia.

\section{INTRODUCTION}

Dysmenorrhea is considered the most common gynecological complaint by young women and affects approximately $60-80 \%$ of the female population. It is characterized by pain in the lower abdomen and may be accompanied by nausea, vomiting, headache, dizziness and fainting ${ }^{1,2}$. Around $8-18 \%$ of that population report intense discomfort, causing absenteeism in several daily activities while suffering pain $^{3}$. 
Dysmenorrhea may be rated in relation to intensity as light, moderate or severe, and to etiology as primary or functional, and secondary or organic ${ }^{1,4}$.

Some resources have been used for the treatment of dysmenorrhea. The use of medicinal plants seems to be effective for the treatment of that dysfunction ${ }^{5}$. Resources such as yoga, acupuncture and acupressure have also been used to treat menstrual pain ${ }^{6,7}$. It has already been shown that the combination of transcutaneous electrical nerve stimulation (TENS) and thermotherapy produces acute pain relief in women with moderate to severe primary dysmenorrhea ${ }^{8}$. Yet, the use of drugs also has efficacy in its treatment ${ }^{9}$.

Among the physical therapy resources available for analgesia, thermotherapy is an option commonly used for the treatment of dysmenorrhea ${ }^{10}$. The application of cold or heat through compresses is a practical and low-cost resource in their treatment ${ }^{10}$. A study ${ }^{11}$ compared groups of 10 participants who received cold or hot compress applied to the lower abdomen, one to two days before the menstrual period, and during the menstrual period. The authors found, through the visual analog scale (VAS) and the McGill Pain Questionnaire, that volunteers who received treatment with cold compress presented a higher satisfaction with the method and a more significant reduction of pain in comparison to those who used heat.

As there are still few studies about the use of non-pharmacological and low-cost resources to reduce the pain during the follicular period, studies are required in order to assess the effectiveness of the options available for that purpose ${ }^{10}$.

The objective of this study was to investigate the influence of a single session of cold compresses versus hot compresses on pain intensity and pressure pain tolerance threshold (PPT) in women with primary dysmenorrhea.

\section{METHODS}

One hundred eleven university students enrolled in higher education in a private educational institution in the city of São Paulo were recruited through direct contact. They were all informed about the research and signed the Free and Informed Consent Term (FICT) prepared according to the recommendations set forth in Resolution 466 of the Brazilian National Health Council and the Declaration of Helsinki.

The inclusion criteria were age between 18 and 30 years, independent walking ability and presence of primary dysmenorrhea. Exclusion criteria were pregnant women, smokers, having children, a history of uterine diseases, and the use of hormonal contraceptives.

Volunteers underwent an individual assessment in a private place for the collection of demographics, age, gender, ethnicity, education, weight, height and pain intensity.

Pain intensity was assessed by VAS ${ }^{12}$. It is a straight line from 0 to $10 \mathrm{~cm}$ drawn on a paper, where on one end is written "no pain" (point zero) and on the other end is "maximum pain" (point 10). Each participant was asked to score on the straight line her level of discomfort. The closer the mark was to the source (zero $\mathrm{cm})$, the lower would be the intensity of pain per- ception. On the other hand, the closer to the end of the line $(10 \mathrm{~cm})$, the higher would be the pain intensity.

Sixty-five women with a history of primary dysmenorrhea and pain by VAS above 4 in the follicular phase were selected to participate in the study. Nevertheless, 15 did not express interest in participating; four were taking drugs, and six gave up participating before the assessment. The final sample consisted of 40 women, randomly divided by a simple draw in two groups: hot compress (HC-n=22) or cold compress $(C \mathrm{C}-\mathrm{n}=18)$.

Participants were also assessed regarding PPT, which measures the pressure the person supports at a particular body site through algometry. The Wagner Force Dial (FDK/FDN SERIES Push Pull Force Gaga, GREENWICH CT, USA) algometer was used for it. The handheld device contains a $1 \mathrm{~cm}$ diameter rubber end. The pressure was applied at a constant velocity of $1 \mathrm{~kg} / \mathrm{sec}$ until the volunteer reported the level of pain or discomfort. The reading is expressed in $\mathrm{kg} / \mathrm{cm}^{2}$. During the assessment, the volunteer was instructed to say "stop" as soon as the feeling of pressure changed from unpleasant to painful. The test was interrupted as soon as the volunteer indicated the onset of pain, and the final amount of force applied was recorded. Algometry was applied in six predefined muscle points, identified below, to assess PPT:

RLP: right lumbar paravertebral region, LLP: left lumbar paravertebral region. In that assessment, the subject remained in the prone position, with lower limbs extended ${ }^{13}$.

SL: supraspinatus ligament L4-L5, L5-S1. The subject remained in lateral decubitus position, with lower limbs extended ${ }^{14}$. RMG: right middle gluteus; LMG: left middle gluteus. For that assessment, the subject remained in lateral decubitus position, with lower limbs extended, as previously described in literature ${ }^{14}$.

Volunteers were assessed for VAS and PPT before, immediately after application of the compress and 30 minutes after its end. Participants were instructed about the study procedures: they should be menstruating, they should not have taken, or taking drugs or any other method of pain relief and wear comfortable clothing at the time of the intervention.

Both groups received the applications on the day when they mentioned higher pain peak. The compresses were placed in the lower abdomen and lower back region for 20 minutes. The volunteer was positioned in lateral decubitus position, and a thin cloth was placed on the application sites in order to avoid burns and improve the fixation of the compresses on the site. The hot bags were made of synthetic rubber and heated with boiling water in an electric kettle. The cold bags were made of plastic containing cellulose-based gel and were kept in the freezer and removed at the time of application.

The Research Ethics Committee of Centro Universitário Adventista de São Paulo (UNASP-SP) approved this study under opinion number 2.141.655, 2017.

\section{Statistical analysis}

The data were analyzed by the SPSS v.24 statistical package for Windows and expressed as means and standard deviations. The demographic data were analyzed with descriptive statistics 
and the Student's t-test performed the comparison between the groups for independent samples. The comparison of the interventions was made by the two-way Analysis of Variance (ANOVA) and to compare the change in the effect of the interventions (delta). The Student's t-test was used for independent samples. The $\alpha$ significance level established in all cases was 5\%.

\section{RESULTS}

Table 1 shows the patients' demographics. The groups happened to be homogeneous with regards to age, weight, height, body mass index (BMI), temperature and perception of pain in VAS. Regarding algometry, no significant changes were observed immediately after the application of the treatments, nor even thirty minutes after the application has finished (Table 2).

The comparison of the effect variation of the interventions (delta between the moments immediately after and before, and between 30 minutes after and before) revealed no significant differences between the two intervention groups, both in relation to thresholds of pressure pain tolerance and as regards to pain perception.

Regarding pain intensity (VAS), both groups presented a decrease in that variable immediately after application and after 30 minutes of its end in relation to the moment before the intervention. Such differences were statistically significant (Table 3). The comparison between the groups in each of the three-time points assessed showed that there was no difference between them regarding pain perception assessed by VAS before the intervention $(\mathrm{p}=0.17)$. However, both after and 30 minutes after the intervention, the CG showed a more significant reduction of pain perception than $\mathrm{HC}(\mathrm{p}=0.002$ and $\mathrm{p}=0.004$, respectively).

Table 1. Demographics data

\begin{tabular}{lccc}
\hline Variables & $\begin{array}{c}\mathrm{HC} \\
(\mathrm{n}=22)\end{array}$ & $\begin{array}{c}\mathrm{CC} \\
(\mathrm{n}=18)\end{array}$ & $\mathrm{p}$-value \\
\hline Age (years) & $20.91 \pm 2.24$ & $21.06 \pm 2.10$ & 0.834 \\
Weight $(\mathrm{kg})$ & $58.62 \pm 9.39$ & $61.73 \pm 16.21$ & 0.478 \\
Height $(\mathrm{m})$ & $1.61 \pm 0.09$ & $1.62 \pm 0.06$ & 0.769 \\
Body mass index $(\mathrm{kg})$ & $22.61 \pm 3.86$ & $23.41 \pm 5.57$ & 0.609 \\
Temperature $\left({ }^{\circ} \mathrm{C}\right)$ & $35.77 \pm 0.54$ & $35.75 \pm 0.53$ & 0.916 \\
Visual analogue scale $(\mathrm{cm})$ & $6.27 \pm 1.77$ & $5.72 \pm 1.98$ & 0.354 \\
\hline
\end{tabular}

Data presented as mean \pm standard deviation. $\mathrm{HC}=$ hot compress group; $\mathrm{CC}=$ cold compress group.
Table 3. Evolution of pain intensity

\begin{tabular}{|c|c|c|}
\hline Visual analog scale & $\mathrm{HC}(\mathrm{n}=22)$ & $\mathrm{CC}(\mathrm{n}=18)$ \\
\hline Before & $6.27 \pm 1.76^{\star}$ & $5.71 \pm 1.98^{\star \star}$ \\
\hline After & $4.23 \pm 1.80$ & $2.59 \pm 1.36$ \\
\hline After $30 \mathrm{~min}$. & $3.53 \pm 2.37$ & $1.70 \pm 1.36$ \\
\hline
\end{tabular}

\section{DISCUSSION}

This study is similar to the survey ${ }^{11}$ in which the efficacy of heat and cold in the treatment of primary dysmenorrhea was observed. The authors included 20 women, divided into two groups: group A consisting of 10 volunteers treated with a heated thermal gel bag, and group B, also consisting of 10 volunteers treated with cold thermal gel bag chilled in the freezer. Both techniques were applied for 20 minutes in the lower abdomen region, one to two days before the onset of menstruation. In this study, the application of the compress was similar to the one in the study mentioned above regarding time length and site of application of the compresses, but it differs in the amount of the sessions. Such authors performed three sessions, one to two days before the beginning of menstruation, and found that cold compress is more effective than a hot one for relieving menstrual pain.

The study assessed volunteers by VAS and also assessed pain by direct measurement, algometry. However, only through VAS it was possible to observe a significant improvement, as already shown by other authors ${ }^{11}$. And data corroborate these authors ${ }^{11}$ in that cold compress is more effective than hot compress to relieve menstrual pain. Another study ${ }^{15}$ showed that the effect of the application of ice on the skin has a direct action on neurons and pain receptors, lowering the speed and the number of nerve impulses. The speed of that effect is due to its action on the gate control of pain mechanism, leading to the release of endorphins and enkephalins, pain-relieving substances.

However, although cold has shown better results concerning the HC group, the latter also obtained benefits in terms of decreased perception of pain intensity. This decrease probably occurred because heat can reduce muscle tension, which would briefly give the sensation of pain reduction, and it

Table 2. Thresholds of pressure pain tolerance before, after and 30 minutes after the interventions

\begin{tabular}{|c|c|c|c|c|c|c|c|}
\hline & \multicolumn{3}{|c|}{$\mathrm{HC}$} & \multicolumn{3}{|c|}{$\mathrm{CC}$} & $\mathrm{p}$-value \\
\hline RMG & $4.77 \pm 2.48$ & $4.01 \pm 2.22$ & $4.09 \pm 2.02$ & $4.60 \pm 1.64$ & $4.25 \pm 1.85$ & $4.35 \pm 1.72$ & NS \\
\hline LLP & $3.67 \pm 1.57$ & $3.63 \pm 1.76$ & $3.71 \pm 1.44$ & $3.85 \pm 1.71$ & $3.56 \pm 1.30$ & $3.83 \pm 1.24$ & NS \\
\hline
\end{tabular}

Values in $\mathrm{kg} / \mathrm{cm}^{2}$, expressed as mean \pm standard deviation. $\mathrm{HC}=$ hot compress group; CC = cold compress group. RMG = right middle gluteus; LMG: left

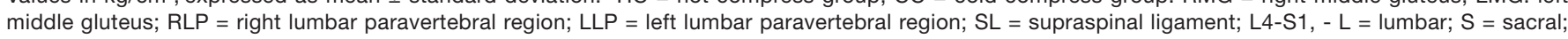
NS = not significant. 
also acts on pain control by means of the gate theory, similarly to TENS, or even changing central pain thresholds or through a well-being sensation ${ }^{16}$. By conducting a review of physical therapy treatments in dysmenorrhea, a study ${ }^{10}$ pointed out that thermotherapy, either by cold or heat, is a recurring treatment for that dysfunction. The authors added that both could eliminate or reduce pain in a practical and economical way.

Also, to demonstrate the effectiveness of therapeutic means as a treatment, a study ${ }^{17}$ estimated the prevalence of primary dysmenorrhea in schoolchildren and compared the impact of exercise and hot water bag in the occurrence and severity of symptoms. The study concluded that both exercises and hot water bags led to a significant improvement in the severity of pain and menstrual distress in the groups studied. Subjects in both groups showed a clear change from moderate and severe degrees to a mild degree of pain. Although the change was evident after the first month of intervention, it became more prominent at the end of the third month in both groups.

Regarding non-pharmacological treatment options for dysmenorrhea, a study reports that interventions such as behavioral therapy, use of medicinal herbs, cutaneous electrostimulation, topical heat use, among others, have been poorly studied yet and lack good quality studies to confirm or not the effectiveness of such resources ${ }^{18}$. Such a statement is in line with a systematic review and meta-analysis reporting that although heat has been used for the treatment of dysmenorrhea, strict quality studies should be conducted in order to provide more robust evidence about that resource ${ }^{19}$.

In this study, VAS and algometry were used to investigate the behavior of acute pain. Probably, no significant changes regarding algometry have been observed after both interventions since the time was short to promote changes in PPT, or it is even possible that the non-significance concerning PPT was due to the performance of a single compress session at the critical moment of pain.

This study has some limitations, such as the lack of a control group. There was also no specific test to confirm the occurrence of dysmenorrhea. Since the perception of pain intensity is a subjective measure, the data related to this variable were collected by self-report of the participants. Also, as pain may have a multifactorial etiology, the homogenization of women concerning the level of physical activity, lifestyle, and variables of emotional origin would possibly provide new information on that matter.

A strength of this study lies in the fact that assessments were performed by the same examiner, who was unaware of the treatment the volunteer had received. The application of the compresses was performed by a properly trained professional who was used to that kind of care, and the application of com- presses was monitored individually to avoid differences in the length of time or form of application among the volunteers.

\section{CONCLUSION}

The application of cold or hot compresses caused no changes in the pressure-pain tolerance threshold in women with primary dysmenorrhea. Though, immediately after the application of compresses and 30 minutes after the end of the intervention, both groups presented a reduction of discomfort caused by pain. However, the CC group had a more significant reduction in pain intensity in comparison to the group that used HC.

\section{REFERENCES}

1. Burnett M, Lemyre M. Primary dysmenorrhea consensus guideline. J Obstet Gynaecol Can. 2017;39(7):585-95.

2. Okusanya BO, Garba KK, Okome GB, Ohiosimuan O. Menstrual pain and associated factors amongst undergraduates of Ambrose Alli University Ekpoma, Edo State, Nigeria. Niger J Med. 2009;18(4):409-12.

3. Osayande AS, Mehulic S. Diagnosis and initial management of dysmenorrhea. Am Fam Physician. 2014;89(5):341-6.

4. Proctor ML, Farquhar CM. Diagnosis and management of dysmenorrhoea. BMJ. 2006; 332(7550): 1134-8.

5. Sanogo R. Medicinal plants traditionally used in Mali for dysmenorrhea. Afr J Tradit Complement Altern Med. 2011;8(5):90-6.

6. Abaraogu UO, Tabansi-Ochuogu CS. As acupressure decreases pain, acupuncture may improve some aspects of quality of life for women with primary dysmenorrhea: a systematic review with meta-analysis. J Acupunct Meridian Stud. 2015;8(5):220-8.

7. Yang NY, Kim SD. Effects of a yoga program on menstrual cramps and menstrual distress in undergraduate students with primary dysmenorrhea: a single-blind, randomized controlled trial. J Altern Complement Med. 2016;22(9):732-8.

8. Lee B, Hong SH, Kim K, Kang WC, No JH, Lee JR, et al. Efficacy of the device combining high-frequency transcutaneous electrical nerve stimulation and thermotherapy for relieving primary dysmenorrhea: a randomized, single-blind, placebo-controlled trial. Eur J Obstet Gynecol Reprod Biol. 2015;194:58-63.

9. Patel JC, Patel PB, Acharya H, Nakum K, Tripathi CB. Efficacy and safety of lornoxicam vs ibuprofen in primary dysmenorrhea: a randomized, double-blind, double dummy, active-controlled, crossover study. Eur J Obstet Gynecol Reprod Biol. 2015;188:118-23.

10. Gerzson LR, Padilha JF, Braz MM, Gasparetto A. Physiotherapy in primary dysmenorrhea: literature review. Rev Dor. 2014;15(4):290-5

11. Araújo IM, Leităo TC, Ventura PL. Comparative study of the efficacy of heat and cold to treat primary dysmenorrhea. Rev Dor. 2010;11(3):218-21.

12. Hawker GA, Mian S, Kendzerska T, French M. Measures of adult pain: Visual Analog Scale for Pain (VAS Pain), Numeric Rating Scale for Pain (NRS Pain), McGill Pain Questionnaire (MPQ), Short-Form McGill Pain Questionnaire (SF-MPQ), Chronic Pain Grade Scale (CPGS), Short Form-36 Bodily Pain Scale (SF-36 BPS), and Measure of Intermittent and Constant Osteoarthritis Pain (ICOAP). Arthritis Care Res. 2011;63(Suppl 11):S240-52.

13. Alfieri FM, Bernardo KM, Pinto YS, Silva NC, Portes LA. Pain tolerance and cardiorespiratory fitness in women with dismenorrhea. Rev Dor. 2017;18(4):311-5.

14. Imamura M, Alfieri FM, Filippo TR, Battistella LR. Pressure pain thresholds in patients with chronic nonspecific low back pain. J Back Musculoskelet Rehabil. 2016;29(2):327-36

15. Low J, Reed A. Eletroterapia Explicada: princípios e prática. São Paulo: Manole; 2001.

16. Akin MD, Weingand KW, Hengehold DA, Goodale MB, Hinkle RT, Smith RP. Continuous low-level topical heat in the treatment of dysmenorrhea. Obstet Gynecol. 2001;97(3):343-9.

17. Chaudhuri A, Singh A, Dhaliwal L. A randomised controlled trial of exercise and hot water bottle in the management of dysmenorrhoea in school girls of Chandigarh, India Indian J Physiol Pharmacol. 2013;57(2):114-22.

18. Ryan SA. The treatment of dysmenorrhea. Pediatr Clin North Am. 2017;64(2):331-42

19. Jo J, Lee $\mathrm{SH}$. Heat therapy for primary dysmenorrhea: a systematic review and meta-analysis of its effect on pain relief and quality of life. Sci Rep. 2018;8(1):16252. 